\title{
ANALISIS DAN PERANCANGAN SISTEM INFORMASI MANAJEMEN PELAPORAN DATA HASIL PANEN BERBASIS WEB PADA DINAS PERTANIAN TANAMAN PANGAN PROVINSI JAMBI
}

\author{
$\underline{\text { Veeny Saputri }}{ }^{1}$, Herry Mulyono ${ }^{2}$ \\ Program Studi Magister Sistem Informasi, STIKOM Dinamika Bangsa, Jambi \\ Jl. Jendral Sudirman, Kec. The Hok, (0741) 35095 \\ Email:veenysaputri@yahoo.com ${ }^{1}$, herrymulyono@stikom-db.ac.id ${ }^{2}$
}

\begin{abstract}
Current management process Reporting of Crops Data at the Office of Food Crops of Jambi Province is a very important process for agencies engaged in agriculture in obtaining information. it is necessary information that can support decision making reporting management of crop data on the Department of Agriculture crops Jambi Province. therefore the author provides solutions in the form of data processing information on each district through web-based applications using use case diagram, activity diagram, and class diagram as a model of system design. for system design limited to prototype. where the results obtained from this study in the form of management information system design that can be implemented further so as to produce information management system reporting of web-based harvest data that can support the process of recording, processing, searching data, until the process of presenting the report on the Office of Food Crops of Jambi Province.

Keywords:Reporting Management System, Department of Food Crops Agriculture, Unified Modeling Language (UML)

Abstrak

Saat ini proses manajemen Pelaporan Data Hasil Panen pada Dinas Pertanian Tanaman Pangan Provinsi Jambi merupakan proses yang sangat penting bagi instansi yang bergerak dibidang pertanian dalam mendapatkan informasi. Maka, diperlukan informasi yang dapat mendukung pengambilan keputusan manajemen pelaporan data hasil panen pada Dinas Pertanian Tanaman Pangan Provinsi Jambi. Oleh karena itu penulis memberikan solusi berupa pengolahan data informasi pada setiap kabupaten melalui aplikasi berbasi web dengan menggunakan Use Case Diagram, Activity Diagram dan Class Diagram sebagai model perancangan sistem. Untuk perancangan sistem sebatas prototype. Dimana hasil yang diperoleh dari penelitian ini berupa rancangan sistem informasi manajemen yang dapat diimplementasikan lebih lanjut sehingga menghasilkan sistem informasi manajemen pelaporan data hasil panen berbasis web yang dapat mendukung proses pencatatan, pengolahan, pencarian data sampai pada proses penyajian laporan pada Dinas Pertanian Tanaman Pangan Provinsi Jambi.
\end{abstract}

Kata Kunci :Sistem Manajemen Pelaporan, Dinas Pertanian Tanaman Pangan, Unified Modelling Language (UML)

(C) 2019 Jurnal Magister Sistem Informasi.

\section{Pendahuluan}

Teknologi informasi merupakan sarana informasi yang sangat penting bagi suatu instansi dalam skala kecil, sedang ataupun besar, sehingga informasi yang diharapkan dapat mempermudah dan memperlancar pekerjaan/kegiatan serta tujuannya dapat tercapai secara optimal dan maksimal. Hal ini perlu dilakukan 
sistem komputerisasi demi mencapai dan mempermudah dalam pengumpulan, pengolahan dan penyimpanan data-data instansi tersebut. Sehingga dalam penyajian informasi data dapat dilakukan secara lengkap, cepat, efisien dan akurat.

Informasi yang akurat, tepat waktu, relevan, dan lengkap dapat memberikan dukungan dalam pengambilan keputusan yang pada akhirnya dapat meningkatkan pertumbuhan kemajuan dibidang Manajemen Pelaporan Data Hasil Panen di Dinas Pertanian Tanaman Pangan Provinsi Jambi.

Proses manajemen Pelaporan Data Hasil Panen pada Dinas Pertanian Tanaman Pangan Provinsi Jambi merupakan proses yang sangat penting bagi instansi yang bergerak dibidang pertanian dalam mendapatkan informasi.Penerapan komputer dan sebuah sistem informasi manajemen Pelaporan Data Hasil Panen menjadi suatu solusi karena dapat mendukung kinerja dalam bagian-bagian yang berhubungan dengan pertanian tanaman pangan serta mendukung pengambilan keputusan bagi Dinas Pertanian Tanaman Pangan Provinsi Jambi dalam meningkatkan kemajuan informasi dibidang pertanian.

Sistem informasi manajemen Pelaporan Data Hasil Panen dapat langsung disajikan baik pada layout layar monitor maupun media cetak. Selain itu proses sistem informasi Pelaporan Data Hasil Panen dapat disajikan secara cepat dan tepat waktu dengan adanya penyimpanan data secara elektronik yang mudah untuk di akses oleh pengguna sistem.

Untuk mengatasi permasalahan-permasalahan tersebut, maka di perlukan adanya pengolahan data informasi pada setiap kabupaten melalui aplikasi berbasi web agar data yang ada tidak lagi di kirim dalam bentuk dokumen dan melalui jasa pengiriman dokumen. Selama ini penerapan sistem informasi manajemen Pelaporan Data Hasil Panen belum sepenuhnya memperhatikan dukungan sistem komputerisasi mulai dari proses pencatatan, pengolahan, pencarian data sampai pada proses penyajian laporan. Kendala yang masih dihadapi saat ini adalah informasi manajemen Pelaporan Data Hasil tidak dapat diperoleh dengan cepat dan penyajian laporan yang belum dilakukan secara spesifik.

\section{Landasan Teori dan Tinjauan Pustaka \\ 2.1 Landasan Teori}

2.1.1 Sistem Informasi

Menurut Laudon $(2012 ; 15)$ sistem informasi secara teknis dapat didefinisikan sebagai " a set of interrelated components that collect (or retrieve), process, store, and distribute information to support decision making and control in an organization".

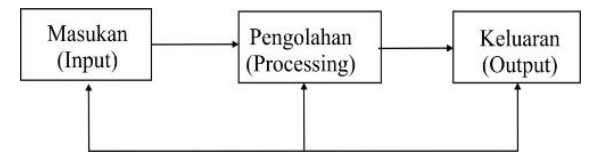

Gambar 2.1 Komponen Sistem Informasi [1]

Sumber :Model Sistem (Hanif Al Fatta; 2007:4)

\subsubsection{Analisis Sistem}

Tahap analisis sistem dilakukan guna untuk mengetahui struktur sistem serta kebutuhan sistem secara mendalam, maka dari itu analisis sistem memiliki komponen penting dalam tujuannya.

Laudon dan P. Laudon $(2012 ; 68)$ menggungkapkan bahwa :

"Systems analysts constitute the principal liaisons between the information systems groups and the rest of the organization. It is the systems analyst's job to translate business problems and requirements into information requirements and systems".

\subsubsection{Desain Sistem}

Menurut Al Fatta (2007; 44), "Desain Sistem adalah sebuah teknik pemecahan masalah yang saling melengkapi (dengan analisis sistem) yang mengangkat kembali bagian-bagian komponen menjadi sistem yang lengkap, harapannya sebuah sistem yang diperbaiki”.

\subsubsection{UML (Unified Modeling Language)}

Pada perkembangan teknologi perangkat lunak, diperlukan adanya bahasa yang digunakan untuk memodelkan perangkat lunak yang akan dibuat dan perlu adanya standarisasi agar orang diberbagai Negara dapat mengerti pemodelan perangkat lunak. Pada perkembangan teknik pemrograman berorientasi objek, muncullah sebuah standarisasi bahasa pemodelan untuk membangun perangkat lunak yang dibangun dengan menggunakan Unified Modelling Language (UML). 
Dennis et. al, (2010 ; 501) mengungkapkan bahwa :"Unified Modeling Language (UML) adalah untuk menyediakan kosakata umum berbasis objek dan teknik diagram yang cukup banyak model untuk setiap proyek pengembangan sistem dari analisis sampai merancang."

Kendall dan Kendall $(2011 ; 309)$ mengungkapkan bahwa "UML adalah alat yang ampuh yang dapat sangat meningkatkan kualitas analisis sistem dan desain, dan dengan demikian membantu menciptakan sistem informasi yang lebih berkualitas ".

\subsubsection{Manajemen Pelaporan Data Hasil Panen \\ 2.1.5.1 Manajemen}

George R. Terry dalam Sulistiono (1998:1)“Manajemen merupakan suatu proses yang khas, yang terdiri dari tindakan-tindakan perencanaan (planning), pengorganisasian (organizing), pengerakan/pelaksanaan (actuating) dan pengawasan (controlling), yang dilakukan untuk menentukan serta mencapai sasaran yang telah ditetapkan serta mencapai sasaran yang sumber daya lain”.

\subsubsection{Pelaporan}

Pelaporan adalah kegiatan berakhir dalam program penilaian, sebagai kegiatan akhir, pelaporan harus disusun dan disampaikan kepada pihak-pihak yang berkepentingan selengkap mungkin sesuai dengan kebutuhan pihak-pihak yang dimaksut, pelaporan merupakan bentuk dokumentasi terhadap seluruh proses kegiatan yang telah dilaksanakan.

Menurut I Gusti Agung Rai (2008 ; 16), Pelaporan merupakan salah satu sarana untuk mewujudkan akuntabilitas organisasi publik. Akuntabilitas pemerintah dibidang kinerja diwujudkan melalui akuntabilitas kinerja istansi pemerintah. Laporan istansi pemerintah bersifat ikhtisar yang menjelaskan secara ringkat dan lengkap tentang pencapaian suatu istansi pemerintahan.

\subsubsection{Data}

Menurut Tata Sutabri (2012;03), Data adalah hal, peristiwa, atau kenyataan lain atau pun yang mengandung sesuatu pengetahuan untuk dijadikan dasar guna penyusunan keterangan, pembuatan kesimpulan, atau penetapan keputusan.

\subsubsection{Hasil Panen}

Menurut Untung Prastio (2015; 10), hasil panen merupakan salah satu untuk mengukur tingkat hasil pertanian pembudidayaan untuk menerapkan beberapa inovasi untuk beberapa hasil yang maksimal mulai dengan mengefisiensikan teknis budidaya sehingga memberikan nutrisi yang dibutuhkan secara maksimal. Namun, mungkin tetap ada sisi ketidakpuasan pembudidaya akan hasil panen yang dipelolehnya.

\subsection{Tinjauan Pustaka}

Tinjauan pustaka menguraikan hasil-hasil penelitian yang pernah dilakukan olehpeneliti sebelumnya yang mempunyai kaitan dengan penelitian ini. Berikut tinjauanpustaka yang terkait dengan penelitian :

\section{Sistem Informasi Hasil Perkebunan Sawit dan penjualan Minyak Mentah pada PT Persada Sawit Mas Palembang}

Penelitian yang dilakukan oleh Vera Agustin, STMIK Palcomtech Palembang yang berjudul "Sistem Informasi Hasil Perkebunan Sawit dan penjualan Minyak Mentah pada PT Persada Sawit Mas Palembang".Dalam penelitiannya mereka mempunyai masalah pada bagian penginputan data hasil panen kelapa sawit dan penjualan minyak mentah yang masih memakai aplikasi sederhana seperti Microsoft Excel dan belum mempunyai aplikasi untuk pengolahan datanya sendiri sehingga menimbulkan kesulitan dalam penginputan data-datanya yang mempunyai banyaknya form-form serta data yang harus diinput terkadang membuat penginputan data salah dalam memasukan data ke dalam form yang seharusnya diisi sehingga memerlukan waktu yang cukup lama untuk melakukan penginputan data, dalam pencarian data hasil panen maupun penjualan minyak mentah menjadi sulit karena banyaknya data yang ada di dalam perusahaan ini tidak disimpan dengan rapi sehingga sering terjadinya kehilangan data hasil panen, laporan hasil panen dan penjualan minyak mentah menjadi terlambat karena sering terjadinya kehilangan data hasil panen. maka vera membuat sebuah sistem informasi menggunakan aplikasi delphi 2007 dan Database SQL server 2008 untuk perusahaan ini yaitu Sistem informasi hasil perkebunan sawit dan penjualan minyak mentah yang dapat mempermudah proses sistem informasi hasil perkebunan, mempermudah penyajian laporan yang dibutuhkan secara cepat dan akurat dan sistem 
informasi hasil panen dan penjualan minyak mentah lebih terstruktur dan efisien semua arsip perencanaan panen, pelaksanaan panen, hasil panen, barang masuk, barang, konsumen, pesanan, penjualan, surat jalan, barang keluar dan pembayaran tercatat dan tersimpan dalam sistem informasi ini.

2. Perancangan Sistem Informasi E-Farming Berbasis Web Untuk Mengetahui Tingkat Kelayakan Panen Pada Sektor Pertanian

Penelitian yang dilakukan oleh Nanda Dian Prasetyo, dkk, 2016 yang berjudul "Perancangan Sistem Informasi E-Farming Berbasis Web Untuk Mengetahui Tingkat Kelayakan Panen Pada Sektor Pertanian" dalam masalah penelitian ini timbulnya beberapa kerugian yang sering timbul akibat tidak adanya sistem perhitungan kelayakan panen pada langkah tahap sebelumnya yaitu turunya angka keuntungan yang diperoleh petani tidak sesuai dengan modal yang telah dipergunakan, banyaknya hasil panen yang tidak berkualitas untuk dijual ke pasar/konsumen, bahkan hingga kerusakan lahan pertanian yang merupakan dampak dari tidak terdeteksinya sejak dini. Sedemikian parahnya dampak tidak adanya sistem informasi pengelolaan kelayakan produksi pertanian, pernyataan tersebut analisa masalah yang dikaji dalam penelitian ini adalah perlu adanya penyediaan sistem informasi yang dapat mendukung pengamatan atas angka kelayakan hasil panen yang akan dihasilkan oleh sektor pertanian, salah satunya sistem informasi E-Farming. Metode yang digunakan analisa dalam penelitian ini Farming System Analysis (FSA), metode pengemenbangan sistem informasi penilaan angka kelayakan panen pada sektor pertanian ini menggunakan metode System Development Life Cycle (SDLC) dengan menggunakan diagram ERD, DFD, untuk pemodelan aplikasi yang dibangun serta menggunakan Adobe Dreamweaver CS5 dan MYSQL-Server sebagai basis data dalam sistem (Sistem Informasi E-Farming berbasis web).

\section{Perancangan Dan Implementasi Aplikasi Pelaporan Perkebunan Berbasis WebGIS Menggunakan Google Fusion Dan Open Data Kit (Studi Kasus Kebun Kopi Banaran)}

Penelitian yang dilakukan oleh Soetrysno Agrapatria, 2016 yang berjudul "Perancangan Dan Implementasi Aplikasi Pelaporan Perkebunan Berbasis WebGIS Menggunakan Google Fusion Dan Open Data Kit (Studi Kasus Kebun Kopi Banaran)". Dalam penelitiannya mereka menemukan kesulitan dalam proses pelaporan pekerjaan sehari-hari sehingga proses pekerjaan dapat dikatakan berjalan lamban. Hal tersebut berdampak pada efisiensi waktu dan menimbulkan potensi kerugian bagi perusahaan. potensi kecurangan yang cukup besar juga dapat terjadi dikarenakan proses pelaporan masih manual menggunakan formulir yang dapat dengan mudah dimanipulasi oleh oknum pekerja. Maka adhikrist merancang sebuah aplikasi sistem pelaporan pada kebun kopi Banaran menggunakan Open Data Kit sebagai data collecting, Google Fusion sebagai tempat penyimpanan data dan Google Maps sebagai media dalam menyampaikan informasi. Diharapkan aplikasi yang digunakan dapat mempercepat proses pelaporan kebun kopi sehingga berjalan tepat waktu. Petugas di lapangan hanya perlu membawa smartphone untuk pengambilan data-data yang dibutuhkan dalam proses penyampaian informasi.

\section{Metode Penelitian}

Agar penelitian dapat berjalan dengan baik, maka kita harus memiliki alur penelitian yang telah disusun sebelumnya. Alur penelitian digunakan sebagai acuan atau pedoman dalam agenda penelitian yang akan dilakukan agar Penulis dapat melakukan penelitian secara terstruktur dan dapat menyelesaikan penelitian tepat pada waktunya, juga agar penelitian dapat berjalan sesuai dengan yang diharapkan.

\subsection{Identifikasi Masalah}

Identifikasi Masalah merupakan langkah awal yang dilakukan dalam penelitian ini. Pada tahap mengidentifikasi masalah dimaksudkan agar dapat memahami masalah yang akan diteliti, sehingga dalam tahap analisis dan perancangan tidak keluar dari permasalahan yang diteliti.

\subsection{Studi Literatur}

Pada tahap studi literatur penulis mempelajari dan memahami teori-teori yang menjadi pedoman dan referensi yang diperoleh dari berbagai buku, jurnal, artikel dan juga internet untuk melengkapi pembendaharaan konsep dan teori, sehingga memiliki landasan dan keilmuan yang baik guna menyelesaikan masalah yang di bahas dalam tesis ini dan mempelajari penelitian yang relevan dengan masalah yang diteliti. 


\subsection{Pengumpulan Data}

Pengumpulan data merupakan tahapan dalam proses yang penting, karena hanya dengan mendapatkan data yang tepat maka proses penelitian akan berlangsung sampai peneliti mendapatkan jawaban dari perumusan masalah yang sudah ditetapkan. Data yang dicari harus sesuai dengan tujuan penelitian. Beberapa metode yang digunakan yaitu :

a. Dokumen Kerja (hard document)

Penulis melakukan pengumpulan data dengan mempelajari dokumen-dokumen yang berkaitan dengan pelaporan data hasil panen. Hal ini dilakukan dengan tujuan untuk mengetahui proses kerja pelaporan hasil panen di Dinas Pertanian Tanaman Pangan Provinsi Jambi.

b. Pengamatan (observation)

Kegiatan observasi ini dilakukan dengan melakukan pengamatan langsung terhadap objek yang akan diteliti guna mengetahui secara langsung mengenai Sistem Informasi pelaporan hasil panen di Dinas Pertanian Tanaman Pangan Provinsi Jambi.

c. Wawancara (Interview)

Penulis melakukan penelitian lapangan dengan cara melakukan wawancara kepada pihak yang berkaitan untuk memperoleh data-data yang dibutuhkan oleh penulis. Hal ini dilakukan agar penulis mengetahui kegiatan apa saja yang dilakukan, serta untuk memperoleh data yang akurat serta relevan agar dapat menghasilkan suatu rancangan website yang sesuai kebutuhan. Wawancara yang dilakukan dengan dua bentuk, yaitu wawancara terstruktur (dilakukan melalui pertanyaanpertanyaan yang telah disiapkan sesuai dengan permasalahan yang akan diteliti). Dan wawancara tidak terstruktur (wawancara dilakukan apabila adanya jawaban berkembang di luar sistem permasalahan).

\subsection{Analisis Sistem}

Proses menganalisis dan membuat rencana Sistem Informasi Manajemen Pelaporan Data Hasil Panen Pada Dinas Pertanian Tanaman Pangan Provinsi Jambi dengan menggunakan pemodelan UML (Unified Modeling Language) yaitu : diagram Use Case, Diagram Class, dan Diagram Activity.

\subsection{Perancangan Sistem}

Berdasarkan metode prototype yang telah dijelaskan pada landasan teori, maka dapat diuraikan pembahasan masing-masing tahap dalam model tersebut adalah sebagai berikut :

a. Communication / Komunikasi

Tim pengembang perangkat lunak melakukan pertemuan dengan para stakeholder untuk menentukan kebutuhan perangkat lunak yang saat itu diketahui dan untuk menggambarkan areaarea dimana definisi lebih jauh untuk iterasi selanjutnya.

b. Quick Plan / Perencanaan Secara Cepat

Dalam perencanaan ini iterasi pembuatan prototipe dilakukan secara cepat. Setelah itu dilakukan pemodelan dalam bentuk "Rancangan cepat".

c. Modeling Quick Design / Model Rancangan Cepat

Pada tahap ini dilakukan pemodelan perencanaan ditahap sebelumnya dengan menggunakan pemodelan terstruktur dalam bentuk model $U M L$, yaitu : diagram Use Case, Diagram Class, dan Diagram Activity. untuk menggambarkan analisis dan desain system.

d. Construction of Prototype / Pembuatan Prototype

Dalam pembuatan rancangan cepat berdasarkan pada representasi aspek-aspek sistem informasi yang akan terlihat oleh para end user (misalnya rancangan antarmuka pengguna atau format tampilan). Rancangan cepat merupakan dasar untuk memulai konstruksi pembuatan prototipe.

e. Deployment Deliery \& Feedback / Penyerahan dan Memberikan Umpan Balik Terhadap Perancangan Prototipe kemudian diserahkan kepada para stakeholder untuk mengevaluasi prototype yang telah dibuat sebelumnya dan memberikan umpan-balik yang akan digunakan untuk memperbaiki spesifikasi kebutuhan. Iterasi terjadi saat perancang melakukan perbaikan terhadap prototipe tersebut.

\subsection{Pembuatan Hasil Laporan}

Pada tahap ini yang dilakukan adalah membuat laporan dari penelitian yang berisikan laporan penelitian terhadap masalah-masalah dan solusi yang ada pada objek yang diteliti oleh penulis yaitu Analisis dan Perancangan Sistem Informasi Manajemen Pelaporan Data Hasil Panen Berbasis Web pada Dinas Pertanian Tanaman Pangan Provinsi Jambi. 


\section{Pembahasan}

4.1 Analisis kebutuhan sistem

4.1.1 Kebutuhan Fungsional Sistem

Analisis kebutuhan sistem merupakan tahap yang penting dalam mengembangkan suatu sistem. Pada tahap ini, kebutuhan pemakai dapat terdefinisikan. Pendefinisian ini akan berdampak pada pembuatan sebuah sistem. Pemahaman kebutuhan yang tepat akan menghasilkan suatu sistem yang sesuai dengam kebutuhan. Oleh karena itu, pendefinisian kebutuhan yang baik akan menjadi faktor kesuksesan dari pengembangan sebuah sistem. Pada penelitian ini berdasarkan tahap sebelumnya, maka fungsi utama yang harus dilakukan oleh sistem yang akan dirancang adalah sebagai berikut :

1. Fungsi Login

Digunakan untuk login atau masuk ke dalam sistem dengan menginputkan username dan password sebelum melakukan tambah, mengubah, menghapus informasi.

2. Fungsi Mengelola Manajemen Admin

Digunakan untuk Mengelola Manajemen Admin pada sistem.

3. Fungsi Mengolah Manajemen User

Mengolah Manajemen User merupakan fungsi yang dilakukan oleh admin untuk menambah dan mengubah Manajemen User.

4. Fungsi Mengelola Laporan Kabupaten

Mengelola Laporan Kabupaten merupakan fungsi yang dilakukan Admin untuk melihat, serta mencetak data laporan.

5. Fungsi mengelola Laporan Rekapitulasi

Mengelola Laporan Rekapitulasi merupakan fungsi Admin untuk melihat, serta mencetak.

6. Fungsi Logout

Digunakan untuk logout atau keluar dari sistem.

\subsubsection{Kebutuhan Non Fungsional Sistem}

Kebutuhan non fungsional sistem dapat menjadi lebih kritis dari fungsional sistem, dimana jika tidak terpenuhi maka sistem tidak dapat digunakan. Berdasarkan kebutuhan fungsional sistem yang telah dijelaskan sebelumnya, maka diharapkan sistem yang dirancang mampu memiliki hal-hal tersebut. Berikut adalah kebutuhan non fungsional sistem dari analisis dan perancangan sistem informasi manajemen pelaporan data hasil panen berbasis web pada dinas pertanian tanaman pangan provinsi Jambi yang akan dirancang :

1. Usability, mudah digunakan / user friendly.

2. Security, mengelola data hanya bisa diakses jika melakukan login.

3. Flexibility, data dapat dirubah-rubah setiap tahunnya.

\subsection{Perancangan Sistem}

4.2.1 Diagram Use Case

Diagram Use Case menjelaskan interaksi antara aktor dengan sistem dan mengetahui fungsionalitas dari setiap aktor. 


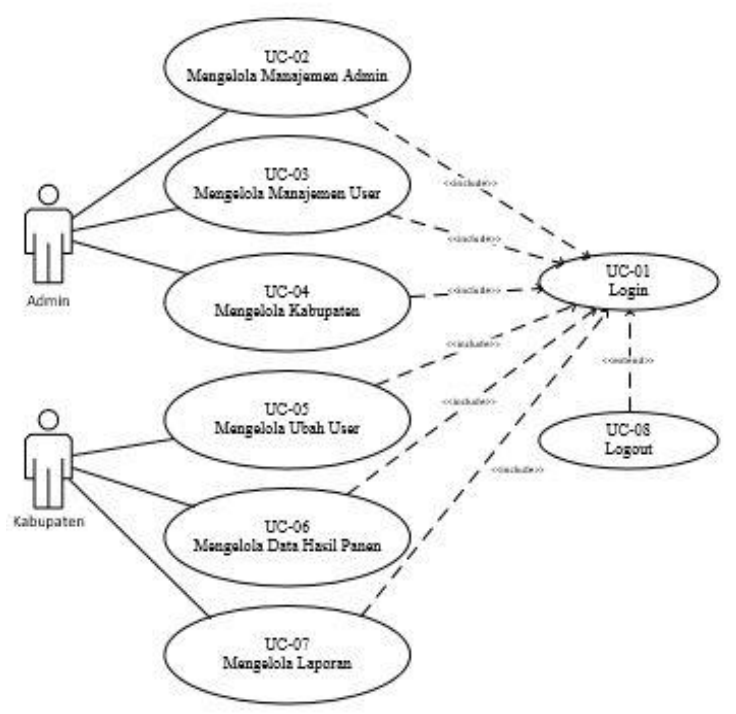

Gambar 4.1 Use Case Diagram [2]

\subsubsection{Activity Diagram}

Activity Diagram adalah representasi grafis dari seluruh tahapan alur kerja. Diagram ini mengandung aktivitas, pilihan tindakan, perulangan dan hasil dari aktivitas tersebut. Pada pemodelan UML, diagram ini dapat digunakan untuk menjelaskan proses bisnis dan alur kerja operasional secara langkah demi langkah dari komponen suatu sistem.Berikut ini adalah ActivityDiagram berdasarkan deskripsi use case sebelumnya, dapat dilihat sebagai berikut:

1. ActivityDiagram Login

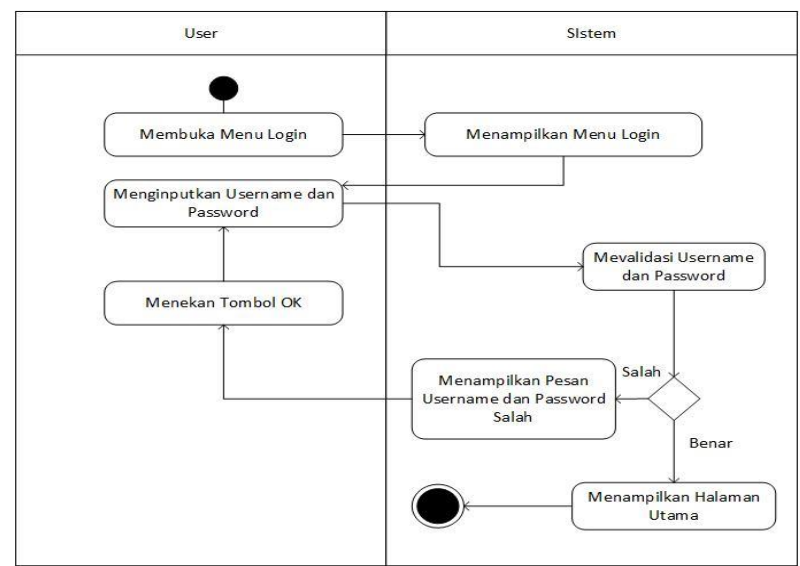

Gambar 4.2 ActivityDiagram Login [3]

2. Activity Diagram Manajemen Admin

a. Menambah Manajemen Admin 


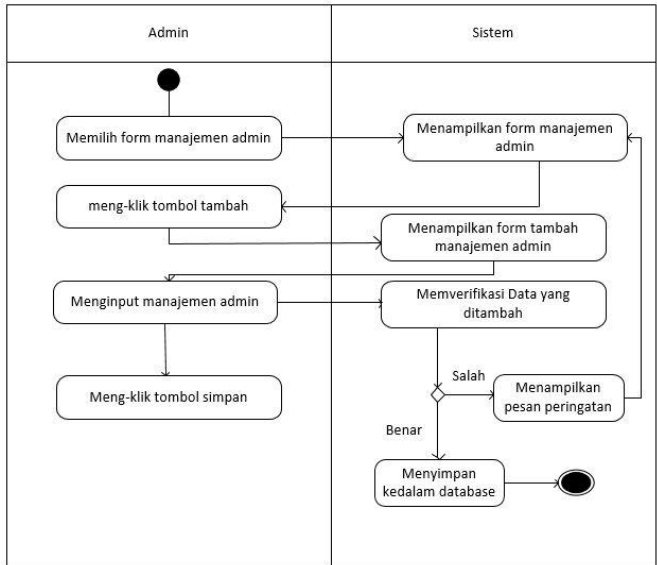

Gambar 4.3 Activity Diagram Menambah Manajemen Admin [4]

b. Menambah Mengubah Admin

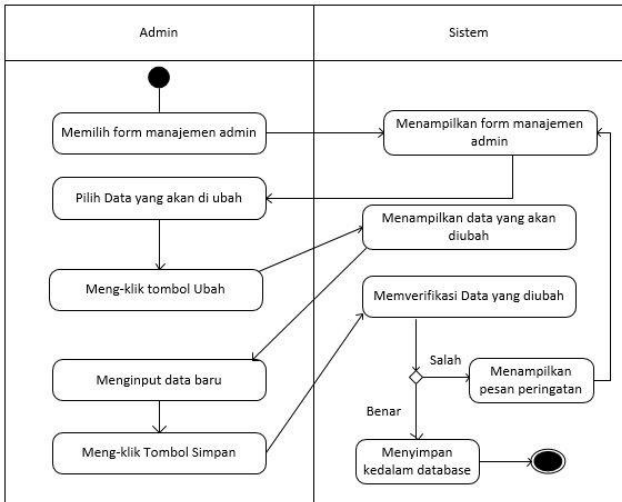

Gambar 4.3 Activity Diagram Mengubah Manajemen Admin [5]

c. Menambah Menghapus Manajemen Admin

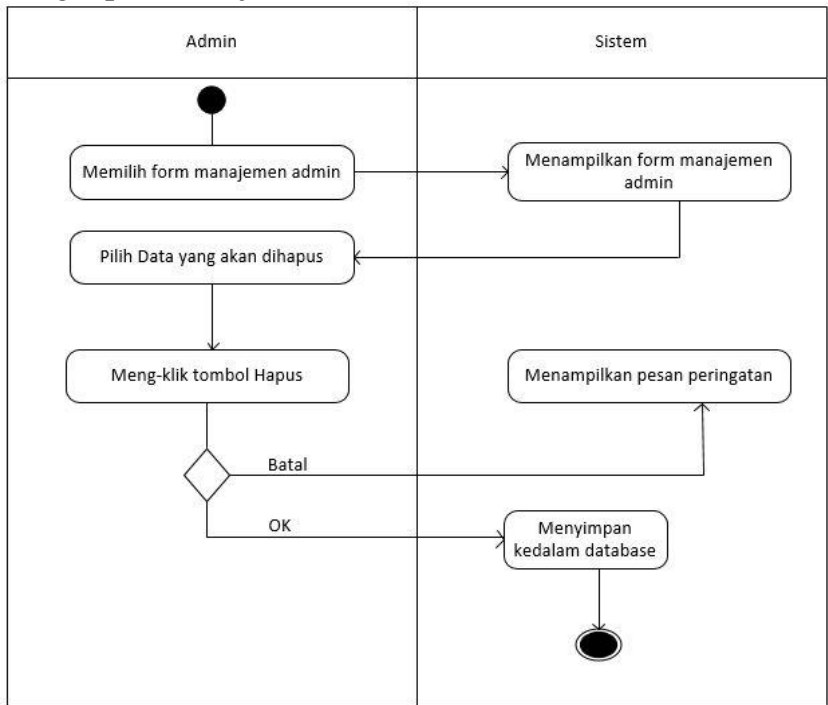

Gambar 4.3 Activity Diagram Menghapus Manajemen Admin [6] 


\subsubsection{Class Diagram} kelas-kelas.

Class Diagram menggambarkan kelas berikut perilaku dan keadaan dengan menghubungkan antara

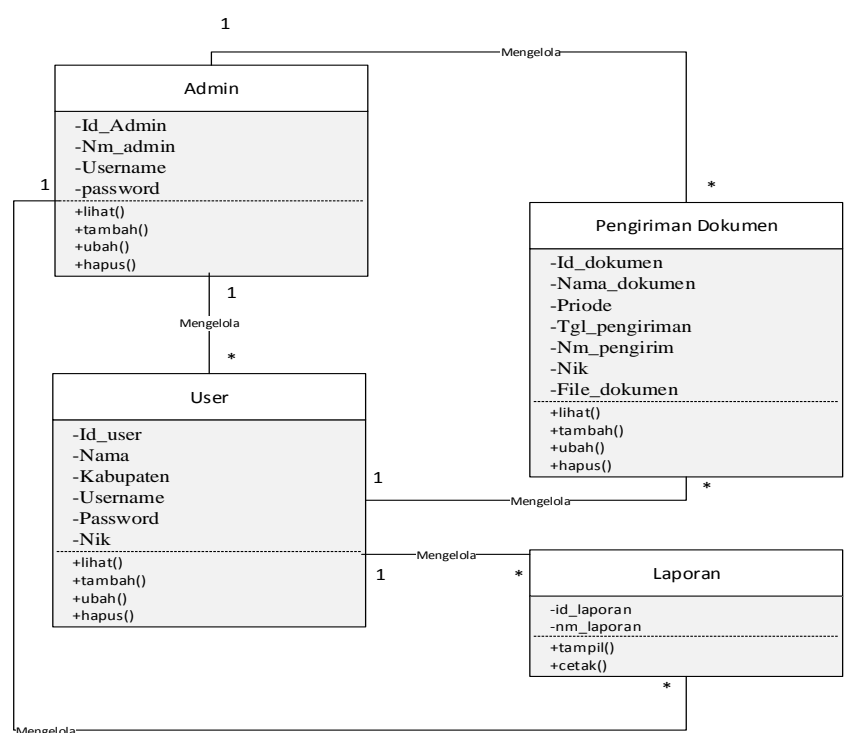

Gambar 4.4Class Diagram [7]

\subsection{Rancangan Input dan Output}

Rancangan input dan output merupakan rancangan dari form-form masukan dari Sistem dan keluaran dari sistem. Berikut adalah racangan inputdan output dari sistem informasi berbasis web pada Dinas Pertanian Tanaman Pangan Provinsi Jambi dapat dilihat sebagai berikut:

1. Rancangan Halaman Login

Berikut adalah rancangan dari halaman login :

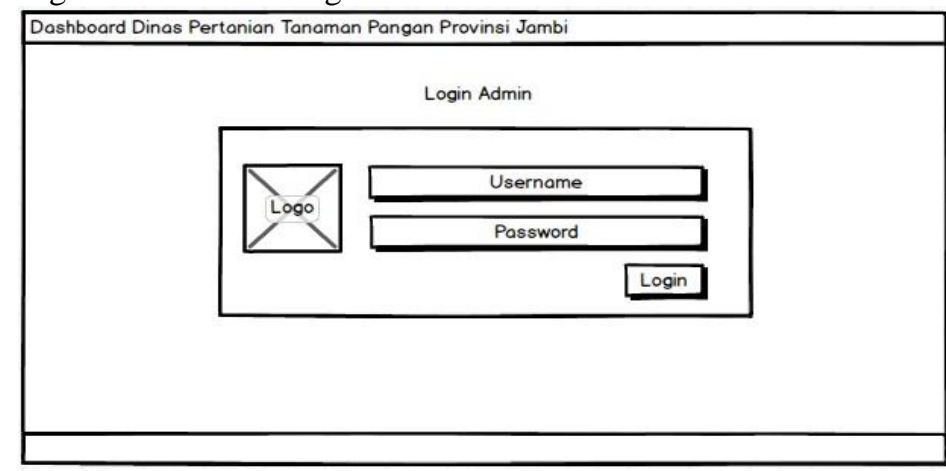

Gambar 4.5 Rancangan Halaman Login [8]

2. Rancangan Halaman Mengelola Manajemen Admin

Berikut adalah rancangan dari halaman mengelola halaman manajemen admin : 


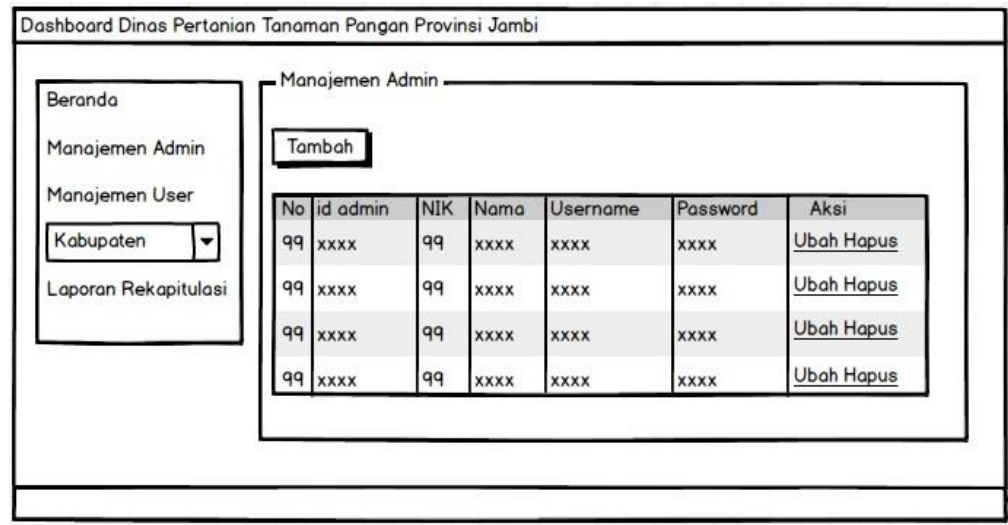

Gambar 4.6 Rancangan Halaman Mengelola Manajemen Admin [9]

3. Rancangan Halaman Mengelola Manajemen User

Berikut adalah rancangan dari halaman mengelola manajemen user :

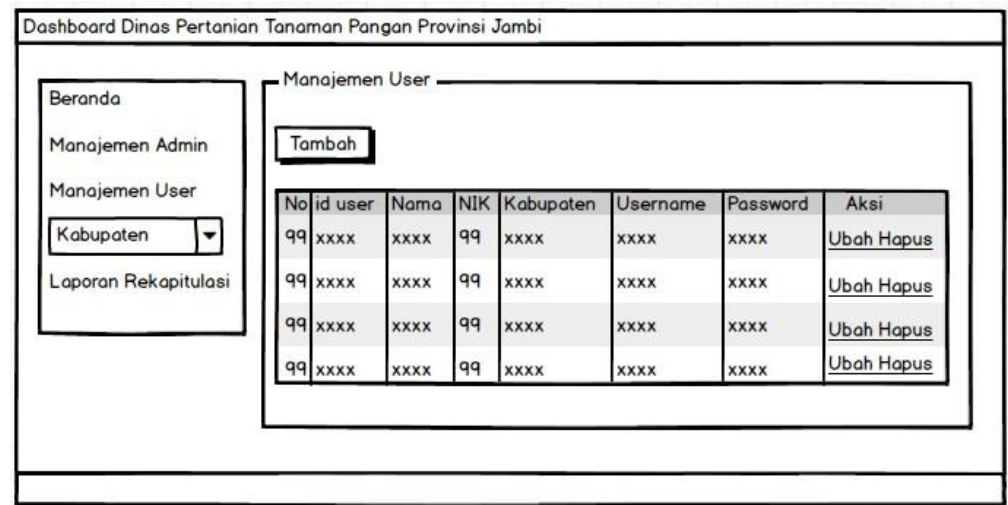

Gambar 4.7Rancangan Halaman Mengelola Manajemen User [10]

4. Rancangan Halaman Mengelola Kabupaten

Berikut adalah rancangan dari halaman mengelola kabupaten :

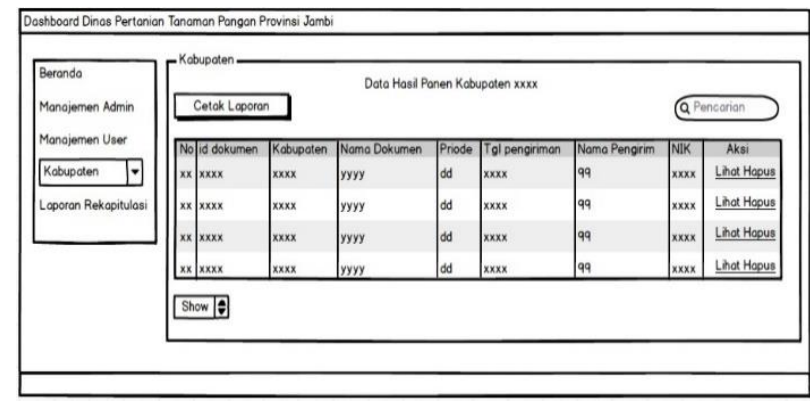

Gambar 4.8 Rancangan Halaman Mengelola Kabupaten [11]

5. Rancangan Halaman Tampilan Rekapitulasi Data Hasil Panen

Berikut adalah rancangan dari halaman tampilan rekapitulasi data hasil panen: 


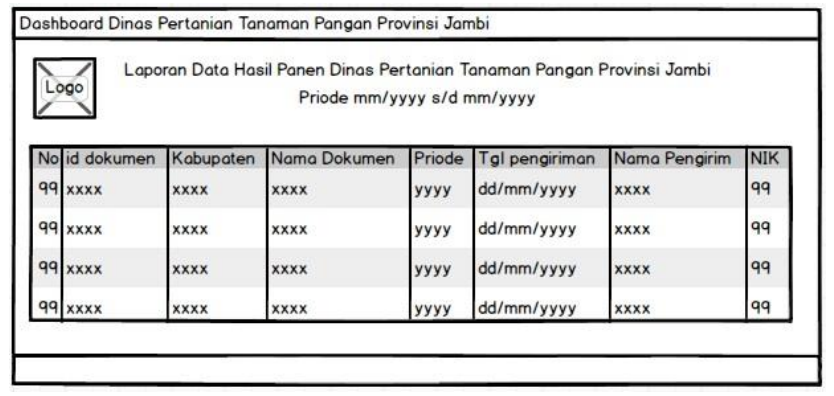

Gambar 4.9Rancangan Halaman Produk Pelaku UMKM [12]

6. Rancangan Tampilan Halaman

Berikut adalah rancangan dari tampilan halaman:

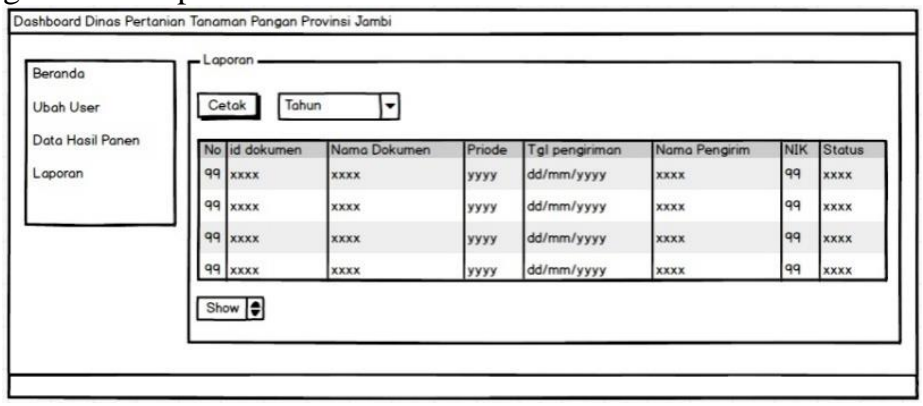

Gambar 4.10Rancangan Tampilan Halaman [13]

7. Rancangan Halaman Logout

Berikut adalah rancangan dari halaman utama Logout :

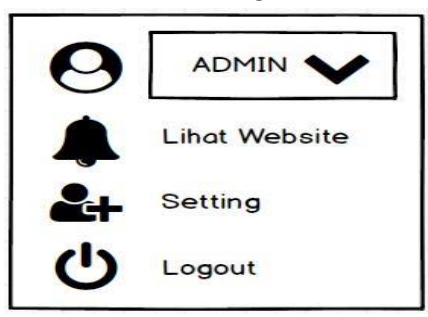

Gambar 4.11RancanganHalaman Logout [14]

\section{Kesimpulan dan Saran}

\subsection{Kesimpulan}

Kesimpulan yang diperoleh setelah melakukan tahapan-tahapan pada penelitian adalah sebagai berikut :

1. Dengan adanya sistem informasi Pelaporan data hasil panen pada Dinas Tanaman Pangan Provinsi, yang sebelumnya dilakukan secara konvensional menimbulkan beberapa masalah, diantaranya membuat data laporan lama sampai dan juga keamanan data kurang terjamin karena melalui proses yang panjang dan juga membuat biaya operasional bertambah.

2. Pengiriman Laporan data hasil panen melalui sistem Informsi berbasis Web akan mempermudah pengolahan data hasil panen pada Dinas Tanaman Pangan Provinsi Jambi.

\subsection{Saran}

Berdasarkan kesimpulan-kesimpulan yang telah dikemukakan, dapat diajukan beberapa saran untuk pengembangan lebih lanjut, antara lain:

1. Rancangan sistem informasi Manajemen pelaporan data hasil panen pada Dinas Pertanian Tanaman Pangan Provinsi yang telah dibuat diharapkan dapat di implementasikan agar dapat membantu manajemen pelaporan data hasil panen dalam mengelola data hasil panen.

2. Agar sistem informasi Manajemen pelaporan data hasil panen pada Dinas Pertanian Tanaman Pangan Provinsi ini lebih efektif maka disarankan agar program yang telah dibuat ini dapat dikembangkan lagi sesuai dengan kebutuhan serta melakukan perawatan dan pemeliharaan perangkat keras dan lunak secara berkala terhadap sistem baru ini. 
3. Bahasan terhadap analisis dan perancangan sistem informasi Manajemen pelaporan data hasil panen telah diidentifikasikan kelemahan sistem yaitu belum ada fitur yang terintegrasi pada Dinas Tanaman Pangan sehingga di sarankan pada peneliti selanjutnya dapat mengembangkan fitur baru yang bisa mengintegrasikan sistem ke seluruh kabupaten.

\section{Daftar Rujukan}

Paper dalam jurnal

[1] Agustina, Vera, 2012. Sistem Informasi Hasil Perkebunan Sawit dan penjualan Minyak Mentah pada PT Persada Sawit Mas Palembang.

[2] Dian Prasetyo, Nanda dkk, 2016. Perancangan Sistem Informasi E-Farming Berbasis Web Untuk Mengetahui Tingkat Kelayakan Panen Pada Sektor Pertanian.

[3] Agrapatria, Soetrysno. 2016. Perancangan Dan Implementasi Aplikasi Pelaporan Perkebunan Berbasis WebGIS Menggunakan Google Fusion Dan Open Data Kit (Studi Kasus Kebun Kopi Banaran).

\section{Buku}

[1] AlanDennis; Wixom, Haley Barbara: \&M.Roth, Roberta. 2010.Systems Analysis and Design. Fourth Edition. United States of America : John Wiley \& Sons, Inc.

[2] Al Fatta, Hanif. 2007. Analisis Dan Perancangan Sistem Informasi. Yogyakarta: Andi.

[3] C. Laudon, Kenneth; \&P. Laudon, Jane. 2012. Management Information Systems (Managing The Digital Firm). Twelfth Edition. United States of America : Pearson Education Inc.

[4] George, R.T. dalam Herujito, M.Y. 2001. Dasar-Dasar Manajemen. Bogor. Grasindo.

[5] Kendall, E. Kenneth; \& Kendall, E. Julie. 2011. Systems Analysis and Design. Eighth Edition. United States of America : Pearson Education Inc.

[6] Prastio, U. 2015. Panen Sayuran Hidroponik Setiap Hari. Jakarta. PT. AgroMedia Pustaka.

[7] Rai, A.G.I. 2008. Audit Kinerja Pada Sektor Publik. Jakarta. Salemba Empat.

[8] Sutabri, Tata. 2012. Konsep Sistem Informasi. Yogyakarta. Andi. 